\title{
Study on the Practice Teaching System of Business Enterprise Management in Colleges and Universities Based on Innovation and Entrepreneurship Ability Training
}

\author{
Yanan Wang \\ Xi’an Fanyi University, 710105
}

Keywords: teaching reform; innovation and entrepreneurship training; business administration; practical teaching system

\begin{abstract}
With the teaching system reform, train the students' practical ability, innovation ability and entrepreneurship ability has become the core content of practical teaching reform in colleges and universities. Therefore, this paper studies the management specialty of university business enterprise, discusses the construction of the practice teaching system of business enterprise management in colleges and universities based on the ability of innovation and entrepreneurship, and expounds the connotation of innovation and entrepreneurship ability and practice teaching system. Moreover, this paper analyzes the characteristics of business administration in colleges and universities, puts forward the scheme of implementing the practice teaching system, and provides reference for the reform of the teaching system in colleges and universities.
\end{abstract}

\section{Introduction}

The difficult employment of college students has puzzled us for many years. In 2013, the ministry of education issued the notice of employment of graduates from ordinary colleges and universities in China, which clearly pointed out that the innovation and entrepreneurship ability training should be the breakthrough point of education. As well as constructing practical teaching system, cultivating practical talents to adapt to social progress and development, and solving the problem of college students' employment difficulties. Therefore, in recent years, universities in our country have carried out education reform. The methods and methods of practical teaching are actively explored through the integration of industry-university-research and school-enterprise union. However, due to the influence of social division of labor and professional difference, the composition of different professional practice teaching system is different. This requires the main analysis object with professional characteristics. We need to integrate innovation and entrepreneurship ability into practice teaching. Then gradually form a scientific and practical teaching system, promote the progress of the discipline and cultivate practical talents.

\section{Innovative Entrepreneurial Ability and Practical Teaching System}

\subsection{Innovative entrepreneurial ability.}

Innovation and entrepreneurship include innovation and entrepreneurship. The ability to innovate is to constantly break through the boundaries of new areas, create new things or improve the existing environment and solve new problems. Innovation ability is a kind of thought and expression of students' self-cognition and knowledge reserve maximization. No one can say that he is a genius. It takes learning to bring knowledge and experience to the extreme and create new ideas, knowledge, methods and results. Therefore, cultivating students' innovative ability is one of the important topics in modern education.

Entrepreneurship is the ability to turn knowledge and experience into economic benefits. The idea is realized through practical activities. Entrepreneurship is a process. For the cultivation of students ability is not confined to professional ability, also includes the management decisionmaking ability, marketing ability, strain capacity, compressive ability and other aspects of 
comprehensive ability. Therefore, entrepreneurship ability is a kind of ability cultivation of students' comprehensive quality, which is an important expression of the talents demand in the new education reform.

The combination of innovation and entrepreneurship ability emphasizes the students' professional level, creative thinking and the application ability of theoretical knowledge. Therefore, the innovation and entrepreneurship ability is the key role that help students to adapt the society and create the society in the modern education.

\subsection{Practical teaching system.}

Practice teaching is a kind of reverse teaching method relative to theory teaching. It is a teaching method to train students' practical ability and application skills and to put theoretical knowledge into practice. Practice education teach through the case, jump out of the book stylized learning method. It is combines with determine the target, content, operation method and method, result assessment and other components. It runs through multiple points of expertise or across expertise. And let students construct their own knowledge system organically and solve practical problems.

The implementation of practical teaching is closely related to social activities. The source of the research is from the field development and innovation project. This kind of teaching method which breaks the traditional theory of learning and practice is based on practice. It will Integrate knowledge and experience into a coherent teaching situation, improve students' independent learning ability and cultivate students' innovative spirit.

\section{Analysis on the Characteristics of Business Administration in Colleges and Universities}

The management major of business enterprise is to cultivate talents in the field of business and enterprise management. It has a wide range of applications and has a very practical role in the market-oriented social development. The training objective about the management talents of industrial and commercial enterprises is the ability to master the theory of business, enterprise management and the ability to use modern management thinking to make business decisions. Students majoring in business administration need to have strong communication skills, rich knowledge structure and familiar with the current enterprise management laws and regulations. Therefore, it is necessary to use practical teaching methods for the cultivation of professional talents in the management of industrial and commercial enterprises to enable students to apply the knowledge flexibly to the goal of qualified talents.

The management major of business enterprise is the channel for conveying management talents to the enterprises. With the development of society and the changing market environment, it is necessary for industrial and commercial enterprise management professionals to innovate with the times. At the same time, they need many skills such as human resource management, financial management and marketing management. It is necessary to combine theory with practice and have the ability to coordinate relations and resources. At present, the management major of business enterprise in colleges and universities has a relatively complete teaching system. However, there are still a lot of deficiencies in talent training target orientation, curriculum setting, talent innovation awareness and practical operation and entrepreneurship ability. First of all, the major of business administration is to cultivate senior management talents. It needs students to have strong practical knowledge application ability. However, the theoretical knowledge learned in the students' school cannot be arranged in accordance with the actual work of positioning after graduation. Second, China's reform and opening up for more than 30 years has formed a relatively perfect market economy system. Through theoretical knowledge, students have mastered the basic management and management theory. But the lack of practical experience and innovative spirit leads to the failure of students to feel the pulse of the market when they go out of school or start their own business. Therefore, the practical teaching of business administration is important to the improvement of curriculum. At the same time, the ability to train and train students' innovative and entrepreneurship ability is a necessary condition for the growth of professional talents in business administration. 


\section{Reform Plan of Teaching System based on Innovation and Entrepreneurship Ability}

\subsection{Teaching objective based on innovation and entrepreneurship ability training.}

The teaching reform goal of business administration in colleges and universities is to stimulate students' ability and thinking in innovation and entrepreneurship. It combines theory with project, systematic and standardized practical teaching system. Then, it will cultivate professional strong, comprehensive ability of industrial and commercial enterprise management professional practical talents. The determination of teaching objectives covers the direction and method of implementation. That is to emphasize the cultivation of students' innovation and entrepreneurship ability. This is fully mobilize the initiative of students' autonomous learning and diverge students' thinking, so that students can create new achievements on the basis of existing research theories and experience. Cultivating students' ability to be an entrepreneur, both in terms of professional skills and comprehensive ability, can achieve the level of participation in social competition. The most effective and direct way to cultivate students' innovation and entrepreneurship ability is to create a practical teaching environment for students. Based on the actual project, the practical teaching experience and the ability to use learning knowledge to solve practical problems flexibly. And to form a complete and standardized teaching system to form the integrated teaching management.

\subsection{The application of practical teaching method.}

The construction of the professional practice teaching system of business enterprise management in colleges and universities should change the existing teaching methods. It has the specialty and the students to carry out the practical teaching reform. In the course of practice, students should master knowledge and understand knowledge and be able to use knowledge flexibly to solve problems. Stimulate students' creativity and creative thinking, have the ability of knowledge expansion and comprehensive application, use cases or projects to make students' grasp of knowledge more secure.

As one of the means to cultivate talents in business administration, practical teaching should strengthen the professional teaching process. Start the comprehensive reform from the teaching goal design, the teaching case design, the teaching software application and the teaching result evaluation in order to improve the students' training effect. For example, the ERP teaching laboratory should be constructed so that students can master the application of ERP system in a comprehensive way and enable students to apply the ERP flexibly through empirical training.

In the course of practice teaching, we should strengthen the connection of each link and monitor the intermediate link. The teaching plan is adjusted by the feedback of students' learning effect, and establish the teaching quality monitoring system. To ensure that every student can acquire knowledge through practical teaching, and take the initiative to realize his/her personal potential, and possess innovative consciousness and entrepreneurship ability. The advantage of practical teaching lies in the ability to enable students to master knowledge and self-learning in practice and cultivate students' awareness of self-learning. This will help students to improve their knowledge level and improve their abilities in the future work, so as to cope with the complex and changing business environment.

We should broaden the thinking and channel of practical teaching, so that students can integrate into the society, and cooperate with the three parties in politics, school and enterprise. We will create innovative incubation bases for college students and use social resources to strengthen students' learning outcomes. We will provide students with a platform to start their own businesses, create conditions for students to start their own businesses, and strengthen the guidance of entrepreneurship. Moreover, we need to arouse students' awareness of self-employment, and turn the idea of entrepreneurship into entrepreneurship action and realize the entrepreneurship dream.

\subsection{Implementation of practical teaching plan.}

The implementation of the practical teaching plan for the management of industrial and commercial enterprises based on innovation and entrepreneurship ability should construct a complete simulation experiment environment. Enable students to use their knowledge flexibly to master modern business management skills. Such as: ERP, SCM, CRM and other information 
system applications. They need to master the technical skills of sand table, cross-border e-commerce and international trade. The students can feel the enterprise environment under the market economy and enhance the effect of the students' practical learning by making the students actually contact with the production and operation process of the enterprise.

In practice teaching, we should enhance the interaction between teachers and students, and students as the main body of learning. We should fully mobilize the initiative of students to study independently. Teachers provide guidance and assistance to the subject research subjects in the course of learning and self-reflection. It will cultivate students' ability to think independently and innovate independently. In our country professional qualification examination standard, already formed a series of qualification examination standard. Students can be encouraged to take the professional qualification examination recognized by the society, such as: certified public accountant, registered asset appraiser, etc. this condition let students deepen their knowledge of professional knowledge through qualifying examinations, and create a good environment for students' future work development.

The key of practical teaching lies in the complete and sustainable training base. Colleges and universities should cooperate with enterprises to enhance mutual trust. We will open up the conditions for students to participate in the training, so that students can have the opportunity and ability to use the enterprise platform to innovate and start their own businesses, and develop a bright future with their own advantages.

\section{Conclusion}

Modern education dominated by market economy. Innovation, entrepreneurship and practical teaching are the important embodiment of education and the era. It is also the main scheme for improving the teaching system. To cultivate talents with rich theoretical knowledge and innovative spirit of the times must start from reality. Base on the enterprise, carry out the school enterprise seamless connection, and let the teaching close to the enterprise development. After graduation, students will be able to take advantage of the society and give full play to their innovative and entrepreneurship abilities. For the management of business enterprise, it is a platform to cultivate excellent management talents, which requires students' innovation and entrepreneurship ability. Therefore, colleges and universities should build a complete practical teaching system from the practical point of view in teaching reform. It is important to deliver outstanding talents for the society, create space for college students to realize their potentials and abilities, and to promote the healthy development of China's economic construction.

\section{Acknowledgement}

1. Project supported by Shaanxi Province Education Science "13th Five-Year" program in 2017(SGH17H473); 2. Support by Research team building of Xi'an Fanyi University (xfu17kytda02)

\section{References}

[1] Guo Zhida, Hua Jucui. Research on the Practice Teaching Reform of Local Colleges and Universities for the Cultivation of Innovation and Entrepreneurship Ability[J] Higher Agricultural Education, 2015(11):56-60

[2] Wang Fangguo. Research on the Cultivation of Innovative Entrepreneurship Ability of College Students Based on Practical Teaching Reform [J] Journal of Higher Education, 2015(3):64-65

[3] Ma Chunlei. Research on the Practical Teaching System of Private Colleges and Universities Based on Innovation and Entrepreneurship Ability Training [J]Research on Transmission Competence, 2017(7)124-126

[4] Zhang Qi, Jin Yuran, Song Wei. Research on the Curriculum System and Practical Teaching 
System Led by "Innovation and Entrepreneurship" -- Taking the Business Administration Major of Liaoning University of Science and Technology as an example[J] Journal of Higher Education, 2016(14):11-12

[5] Du Jun, Shang Yuhe. Research on the Reform of Business Administration Practice Teaching -Based on the Cultivation of College Students' Innovation and Entrepreneurship Ability[J] Modern Business Trade Industry,2017(8):155-158 